\title{
Correction: A survey of foot problems in community-dwelling older Greek Australians
}

\author{
Patricia Kaoulla ${ }^{1}$, Nicoletta Frescos ${ }^{1}$ and Hylton B Menz ${ }^{2^{*}}$
}

\section{Correction}

Since the publication of our Research article [1], the copyright of the Manchester Foot Pain and Disability Index (MFPDI) now states a licence agreement is required for publication. As a result, Additional file 2 has been removed, the English language version of the MFPDI can be found through the ISIS Outcomes website [2].

\section{Author details}

'Department of Podiatry, Faculty of Health Sciences, La Trobe University, Bundoora, Victoria, Australia. ${ }^{2}$ Musculoskeletal Research Centre, Faculty of Health Sciences, La Trobe University, Bundoora, Victoria, Australia.

\section{Received: 4 April 2013 Accepted: 4 April 2013}

Published: 5 April 2013

\section{References}

1. Kaoulla P, Frescos N, Menz HB: A survey of foot problems in communitydwelling older Greek Australians. J Foot Ankle Res 2011, 4:23.

2. ISIS Outcomes - The Manchester Foot Pain and Disability Index (MFPDI). http:// www.isis-innovation.com/outcomes/rheumatology/mfpdi.html.

\footnotetext{
* Correspondence: h.menz@latrobe.edu.au

${ }^{2}$ Musculoskeletal Research Centre, Faculty of Health Sciences, La Trobe University, Bundoora, Victoria, Australia

Full list of author information is available at the end of the article
}

\section{Submit your next manuscript to BioMed Central} and take full advantage of:

- Convenient online submission

- Thorough peer review

- No space constraints or color figure charges

- Immediate publication on acceptance

- Inclusion in PubMed, CAS, Scopus and Google Scholar

- Research which is freely available for redistribution

Submit your manuscript at www.biomedcentral.com/submit 